\title{
Collaboration Between Nonprofit Universities and Commercial Enterprises: The Rationale for Exempting Nonprofit Universities from Federal Income Taxation
}

\author{
James T.Y. Yang
}

Many nonprofit colleges and universities ${ }^{1}$ engaged in scientific research have turned eagerly to collaboration with commercial enterprises. ${ }^{2} \mathrm{Al}-$ though these collaborations take various forms, the most common being research contracts, they all, as the term collaboration implies, impose certain obligations on the universities. For example, in exchange for initial funding and other compensation, universities are often obliged to disclose and assign their research results exclusively to their commercial sponsors who exploit the results for profit.

Such collaborations can erode the independence and integrity of the universities, especially when the scope of the collaborations is extensive. One of the largest collaborations to date is a seventy million dollar contract, funded by Hoechst A.G., a West German chemical corporation, to create a department of molecular biology at Massachusetts General Hospital, an affiliate of Harvard Medical School..$^{3}$ Although the agreement

1. Professor Hansmann defines a nonprofit organization as "an organization that is barred from distributing its net earnings, if any, to individuals who exercise control over it, such as members, officers, directors, or trustees." Hansmann, The Role of Nonprofit Enterprise, 89 YALE L.J. 835, 838 (1980) [hereinafter cited as Hansmann, The Role of Nonprofit Enterprise].

2. For general accounts and discussions of collaborative ventures, see Bouton, Academic Research and Big Business: A Delicate Balance, N.Y. Times, Sept. 11, 1983, $§ 6$ (Magazine), at 62; Sanger, Corporate Links Worry Scholars, N.Y. Times, Oct. 17, 1982, at F4, col. 3; Reinhold, Stanford and Industry Forge New Research Link, N.Y. Times, Feb. 10, 1984, at A22, col. 2; Coast Teachers Warned On Ties to Corporations, N.Y. Times, Feb. 8, 1983, at A16, col. 1.

Various forms of collaboration have evolved between universities and industry. In general, they fall into one of the following categories: 1) research grants and contracts, 2) consulting, 3) affiliate programs, 4) university consortia, 5) industry cooperatives, 6) exchanges of personnel, and 7) industrial parks. For a description of these forms of collaboration, see Low, The Organization of Industrial Relationships in Universities, in PARTNERS IN THE RESEARCH ENTERPRISE 68, 71-73 (T. Langfitt, S. Hackney, A. Fishman \& A. Glowasky eds. 1983) [hereinafter cited as PARTNERs]; Langfitt, Epilogue, in PARTNers, supra, at 167, 168-71. See generally Peters \& Fusfeld, Current U.S. UniversityIndustry Research Connection, in UNIVERSITY-INDUSTRY RESEARCH: SEIECTED STUdies 1, 67-107 (Nat'l Science Found. ed. 1982) (study of university-industry research relationships).

3. In return the contract provides Hoechst with first rights to any patentable discoveries made by the department and allows the company a three-year exclusive license on any developments it chooses 
guarantees that Hoechst will not dictate the specific type of research conducted, Massachusetts General Hospital predictably will be influenced either by its hope of renewing this unique and what must seem like an irreplaceable source of funds or by the all too simple human desire of maintaining collegiality while the collaboration lasts. ${ }^{4}$

Research colleges and universities ${ }^{5}$ are exempt from federal income tax under section 501(c)(3) of the Internal Revenue Code. ${ }^{6}$ Despite being a permanent feature of the federal tax system, ${ }^{7}$ no clear rationale for the exemption has been developed. The Code simply lists exempt purposes, such as "charitable,"8 "scientific," and "educational."10 Consequently, the present tax provisions are vague, confused, overly generous, and even contradictory when applied to research universities that carry out several exempt activities, thus allowing them to serve as de facto instruments of commercial enterprise. Although this Note takes no position on the merit of using the Internal Revenue Code and Service to encourage and police nonprofit organizations, it does presume that they currently serve these important functions. ${ }^{11}$ To preserve the unique functions of the research

to license and a non-exclusive license thereafter. In addition, Hoechst was able to designate a researcher who was not already a part of the hospital to head the program. See Bouton, supra note 2, at 62; Sanger, supra note 2, at F4, col. 3.

4. The size of the contract combined with the fact that Hoechst was the department's sole support and was able to designate an outside researcher to head the program caused critics to charge that major chemical and drug concerns are identifying certain university laboratories for "takeover." See Sanger, supra note 2, at F4, col. 3 .

5. The term "university" will be used in this Note to mean "colleges" and "universities" referred to in I.R.C. $\$ 512(\mathrm{~b})(8)$ (1982). See infra note 83 and accompanying text. Neither the Code nor the regulations defines a college or university. One commentator suggests that "the terms certainly connote the granting of degrees to members of the student body." Kertz, Tax Exempt Organizations and Commercially Sponsored Scientific Research, 9 J.C. \& U.L. 69, 71 n.6 (1982-83).

6. Section numbers, unless otherwise indicated, are references to the Internal Revenue Code of 1954 [hereinafter cited as I.R.C. or the Code], as amended to the date of this Note.

This Note is concerned with the exemption from federal taxation of the income of nonprofit organizations. It will not deal with the charitable deduction as set forth in I.R.C. $§ 170$ (1982) (individual who makes contribution to qualifying nonprofit may deduct amount of contribution from income when computing personal income tax). The Note will also not address limitations which might be imposed by state, local, or other tax laws.

7. Since 1895 Congress has consistently exempted organizations organized and operated for certain purposes from federal income tax. Section 32 of the Tariff Act of 1894 provided for the exemption from tax of "corporations, companies or associations organized and conducted solely for charitable, religious, or educational purposes. . . Tariff Act of 1894 , ch. $349, \S 32,28$ Stat. 509, 556. In 1913 the statutory provision was amended to explicitly provide a reference to "scientific" purposes. Tariff Act of 1913, ch. 16, $\$ \mathrm{II}(\mathrm{G})(\mathrm{a}), 38$ Stat. 114, 172.

8. See infra note 34 .

9. See infra notes 55-57 and accompanying text.

10. See infra note 36 .

11. Nonprofit universities are generally created in the form of corporations. Although virtually all states authorize the attorney general, either by common law or by statute, to supervise charitable corporations, including universities, most states have exercised the attorney general's powers only minimally. "Commonly, little or no staff in the attorney general's office is assigned to look after the affairs of nonprofits, and no effective system of financial reporting by nonprofits exists. . . "Hansmann, Reforming Nonprofit Corporation Law, 129 U. PA. L. REv. 497, 601 (1981) (footnote omitted) 
universities in this time of increasing collaborations, therefore, it is important to identify a clearer rationale for exempting research universities from federal income tax.

In determining this rationale, the subsidiary question of why a particular service is provided by nonprofit organizations rather than by the government must also be answered. Activities that are of social interest to the community are carried on not only by nonprofit organizations and commercial enterprises, but also by our government itself. Instead of relying upon tax exemption to indirectly fund university research, our government can either directly purchase research by grants and contracts, or it can establish its own research organizations. Only after understanding why indirect funding is more desirable, therefore, will the rationale for tax exemption become clearer and complete.

In Part I, this Note sketches the reason for the recent upsurge of collaborations and summarizes the public concerns regarding these new arrangements. Part II offers a rationale for exempting research universities from tax. Based on this proposed rationale, Part III surveys and critiques the existing tax provisions. Part IV refines this rationale by answering the subsidiary question of why a particular service is provided by nonprofit organizations rather than by the government directly. Finally, Part V identifies the appropriate role of the tax provisions in regulating the collaborations and proposes amendments to the existing provisions consistent with the purpose of the exemption.

\section{The Increasing Collaboration}

The recent upsurge of industry-university contracts has stirred considerable controversy. Universities and commercial enterprises, of course, pursue fundamentally very different goals. ${ }^{12}$ Universities seek to protect and foster an environment conducive to free inquiry, the advancement of knowledge, and an open exchange of ideas. ${ }^{13}$ Commercial enterprises, on the other hand, are motivated by the desire for profit. ${ }^{14}$ Knowledge is one among many corporate assets that can generate profits, especially when it

[hereinafter cited as Hansmann, Reforming Nonprofit Corporation Law]. Due to this ineffective regulation of nonprofit corporations, federal agencies have become an important alternative mechanism for regulation. Since nonprofit universities are exempted from the federal income tax, the IRS, in policing transactions to ensure that those upon whom taxes are levied actually pay them, has become an important mechanism for policing the universities. But see Hansmann, Reforming Nonprofit Corporation Law, supra, at 602-06 (IRS's policing efforts are dictated primarily by goal of producing revenue; its ability to police fiduciary behavior of nonprofit is limited).

12. Giamatti, Free Market and Free Inquiry: The University, Industry, and Cooperative Research, in Partiners, supra note 2, at $3,5$.

13. Id. at 4.

14. Id. at 5 . 
can be made proprietary and secret from potential competitors. ${ }^{15}$ These conflicting goals can lead to disputes between academic and industry concerning, among other things, publication of the results of the research, patent rights, licenses, and confidentiality. ${ }^{16}$

University collaboration with industry may also lead to an erosion of academic freedom. ${ }^{17}$ Ideally, academic research should be carried on with no specific direction beyond the quest for new knowledge. ${ }^{18}$ Universities, therefore, stress that researchers should set their own research priorities. ${ }^{10}$ Corporate research, on the other hand, is seldom "non-directed" in the academic sense-it tends to seek particular pieces of knowledge, usually those that will improve an existing product or create a specific new one. ${ }^{20}$ An influx of corporate funding, or even the desire to attract it, may therefore lead universities to scrutinize more carefully the economic promise of their research, thereby influencing the direction of research. ${ }^{21}$ The conflicting social missions of universities and commercial enterprises have already led to research agreements that greatly compromise the unique functions of universities. One agreement, for example, has established an eight-person committee to make funding decisions. Membership on the committee is split evenly between company and university personnel. ${ }^{22}$ As Congressman Gore has commented, “you don't have to know algebra to figure out how the committee works. No research can be done unless the company gives permission."23

The potential problems of university-industry collaborations are enor-

15. Id.

16. See Office of The General Counsel, Nat'l. Science Found., Report on a National Science Foundation Workshop on Intellectual Property Rights in Industry-University Cooperative Research, in UnIVERSITY-INDUSTRY ReseARCh Relationships: SELECTEd Studies 256, 260-65 (Nat'l Science Found. ed. 1982).

17. The need to scrutinize the economic promise of research may compromise the academic imperative to pursue research directions based primarily on their scientific merit. See Bouton, supra note 2, at 63 (industry may not tolerate basic research which "may or may not lead to anything practical").

18. See, e.g., Report of the Committee on Cooperative Research, Patents, and Licensing: Yale University, at 1, 2 (available in Office of Provost, Yale University) [hereinafter cited as as Yale Report] (essential purpose of university is "to preserve and enlarge humanity's store of knowledge").

19. See, e.g., Bok, President's Report: Business and the Academy, Harv. Mag., May-June 1981, at 26. According to Harvard president Bok:

In carrying out their research, able scientists must have wide discretion in choosing which problems to explore, for the practical applications of their work are so unpredictable and the process of creativity so personal and demanding that even the wisest planners could not succeed if they tried to direct all scientific inquiry toward specific, predetermined goals. Id.

20. See infra note 48.

21. See Bok, supra note 19, at 28. Despite being an essential principle of the university, disinterested or free inquiry has never been absolute. See Omenn, University-Corporate Relations in Science and Technology: An Analysis of Specific Models, in PARTNERs, supra note 2, at 20, 21.

22. Sanger, supra note 2 , at F4, col. 5.

23. Id. Another example of controversial collaboration is the $\$ 70$ million contract between Hoechst and Harvard. See supra notes 3-4 and accompanying text. 
mous. So, however, are the benefits. Several reasons have been suggested for the increasing popularity of these collaborations. ${ }^{24}$ Commercial enterprises depend on universities to gain access to high quality and scarce manpower ${ }^{25}$ and to inform them of the most current research being done. ${ }^{26}$ These are high priorities in rapidly changing industries such as biotechnology and microelectronics. The rapid developments in these fields caught many companies off guard, compelling them to turn to the universities that have spawned and will continue to spawn many new industries. ${ }^{27}$

Of primary importance from the university's standpoint is money. Faced with tightening budgets and declining enrollments, universities need new ways to support and enlarge their research activities; they also need industrial funding to compensate for the sudden swings in federal support $^{\mathbf{2 8}}$ and to supplement it at a time when no growth in federal spending is expected. ${ }^{29}$ In addition, academics have expressed a growing sense of "civic responsibility" to make their research available for the public's welfare and to shorten the time lag between the creation of a new scientific concept and its general application. ${ }^{30}$ This sense of civic responsibility is

24. Because of differing needs and structures, the motivations for interaction differ between industry and universities. For extensive and comprehensive discussions of these motivations, see Peters \& Fusfeld, supra note 2, at 34-36; National Science Foundation, University-Industry ReSEARc:h Rri.ationships: MYth, Realities and Potentials 29-30 (1982) [hereinafter cited as N.S.F. REPORTs]; Fusfeld, Overview of University-Industry Research Interactions, in PARTNERS, supra note 2 , at $10,10-12$.

25. See Peters \& Fusfeld, supra note 2, at 34-35 (75\% of company representatives surveyed stated manpower was motivating factor in their support of university research); Fusfeld, supra note 24, at 13 (trained personnel is principal basis for university-industry cooperation).

26. See Peters \& Fusfeld, supra note 2, at 35 (collaboration gives industry a "window" into university research).

27. See id. at 35 (short technology transfer cycle in rapidly changing industries require both university and industry to participate in all aspects of cycle). 46.

28. See Press, Core Technologies and the National Economy, in PARTnERs, supra note 2, at 40,

29. Between 1976 and 1980 , federal funding for basic scientific research increased at a healthy rate of 5.9\% annually after inflation; the rate of increase has since come to a standstill. Although in his fiscal 1984 budget request, President Reagan proposed an $8.5 \%$ increase for basic science, this generous figure includes a $10.3 \%$ increase for Defense Department basic research. In the health sciences, funding is set to increase only by $3 \%$, and the proposed increase of $\$ 73$ million for the National Institute of Health ("N.I.H.") is only $1.8 \%$. The N.I.H. finances $40 \%$ of all biomedical research in the country and pays for nearly two-thirds of basic research undertaken by universities. See Bouton, supra note 2 , at 62 .

While traditional funding has stagnated, the cost of certain research has greatly increased. See Peters \& Fusfeld, supra note 2, at 120 ("Modern research depends upon advanced instrumentation, so that the capital cost per researcher is increasing."). Ironically, while money is lacking, new discoveries in life sciences which could revolutionize health care are proliferating at an unprecedented rate. Bouton, supra note 2, at 62.

30. See, e.g., Bok, supra note 19, at 23, 25 ("Universities have obviously felt a civic responsibility to answer appeals to think about collaborative efforts to increase productivity."); Yale Report, supra note 18 , at 1 (" $A$ closer link between university research and applied industrial technology creates ... attractive opportunities for the practical application of ideas with potentially enormous social benefit."). 
most easily fulfilled in partnership with private enterprises that specialize in the practical application of research results. ${ }^{31}$ Finally, many of the new discoveries are immediately applicable to practical uses. It is no longer realistic to cling to the traditional rigid distinction between research undertaken for knowledge and research undertaken for profit. As business and nonprofit activities increasingly overlap, the presence of commercial enterprises in a particular field can and should no longer of itself preclude the participation of nonprofit universities.

\section{The Rationale for Exemption and Its Implications}

The potential benefit and harm of the recent industry-university collaborations have provoked some universities to reexamine and to revise their policies regarding, among other things, commercially sponsored research, outside activities of their faculties, and patent and licensing practices. ${ }^{32}$ Such self-regulations are reassuring, though they assume bargaining power on the part of universities at a time when many of them are simply groping for survival. To delay or prevent universities from turning into de facto commercial enterprises, therefore, the government may have to step in and provide either sanctions or incentives such as tax exemption. In determining the precise role of the Internal Revenue Code in regulating the controversial research collaborations, however, it must be kept in mind that the goals of a tax code do not necessarily coincide with those of nonprofit universities. Not all of the arguments for or against collaboration can be imported indiscriminately into the consideration of an exemption.

Section 501(c)(3) ${ }^{3 s}$ of the Internal Revenue Code provides, in part, for exemption from federal income tax of organizations "organized and operated exclusively" for charitable, ${ }^{34}$ scientific $^{35}$ or educational ${ }^{38}$ purposes. ${ }^{37}$

31. See Fusfeld, supra note 24 , at 18 ("Since industry is the principal mechanism in our society for converting knowledge to economic use, cooperation with industry is an important avenue for deriving social benefit.").

32. See, e.g., Yale Report, supra note 18, at 1 (Yale recommends guidelines for collaborative research). Universities have also initiated several conferences to discuss issues raised by collaborative research. For statements and reports from two major conferences, see Pajaro Dunes Conference: Draft Statement, 9 J.C. \& U.L. 533 (1982-83) (Pajaro Dunes Conference); ParTwers, supra note 2 ("Partners in the Research Enterprise" Conference).

33. I.R.C. $§ 501$ (c)(3) (West Supp. 1985).

34. The regulations state that the term "charitable" is to be construed in its "generally accepted legal sense. . . Such term includes: . . . advancement of education or science. . . "Treas. Reg. § 1.501 (c)(3)-1(d)(2) (1959) (emphasis added).

35. See infra notes 55-57 and accompanying text.

36. The regulations define "educational organizations" as those that instruct or train the individual "for the purpose of improving or developing his capabilities" or instruct the "public on subjects useful to the individual and beneficial to the community." Treas. Reg. $\$ 1.501$ (c)(3)-1(d)(3) (1959). Organizations that instruct or train the individual include schools, such as public or private colleges, and professional or trade schools. Treas. Reg. $\$ 1.501$ (c)(3)-1(d)(3)(ii)(1) (1959).

37. The term "scientific" intersects with other categories of exempt purposes separately stated in 
Each of these exempt purposes is defined independently by the Treasury. Neither the Code nor the Treasury Regulation, however, indicate how these exempt categories are determined and defined. One commentator has correctly observed that these categories of tax-exempt organizations "are not the result of any planned legislative scheme and have never been set forth as part of any unified concept of exemption. They were enacted over a period of eighty years by a variety of legislators for a variety of reasons." 38

The only apparent criterion unifying all the definition of exempt functions is a vague public interest requirement prescribed by the Treasury: ${ }^{39}$

$\$ 501(c)(3)$ such as "educational" and "charitable." Organizations such as research universities will, therefore, have several bases for tax exemption. For example, in fulfilling the public interest requirement for exemption, many research organizations publish and disseminate their discoveries in an instructional manner. Such instructional activities may be extensive enough to result in qualification as an educational, as well as a scientific, organization. See, e.g., Rev. Rul. 76-455, 1976-2 C.B. 150 (organization that assisted establishment of regional health data system, conducted studies regarding quality, utilization and effectiveness of health care, and educated health care professionals held exempt as educational and scientific organization); Rev. Rul. 65-298, 1965-2 C.B. 163 (organization carrying on research to develop scientific methods for the diagnosis, prevention, and treatment of diseases, and to disseminate results to physicians and public through seminars qualifies as educational organization). Research activities undertaken by organizations organized and operated primarily for educational purpose may also qualify as scientific activities. See, e.g., Rev. Rul. 65-60, 1965-1 C.B. 231 (research activities undertaken by organization "solely in furtherance" of its primary educational purpose constitute exempt scientific activities).

Research universities, in particular, will have several bases for tax exemption, including charitable, educational, and scientific purposes. The finding that an activity carried on by a university furthers any of these bases is sufficient for exemption. See, e.g., Priv. Ltr. Rul. 8445007 (July 24, 1984) (Tech. $\Lambda \mathrm{dv}$. Mem.) (major industry service projects undertaken by laboratory facility which resulted in "90 publications, 99 scientific presentations and 56 undergraduate and post-graduate degrees" did contribute to laboratory's educational role); Priv. Ltr. Rul. 7936006 (May 23, 1979) (Tech. Adv. Mem.) (research funded by pharmaceutical manufacturers and undertaken by medical college researchers was central to basic purposes of promoting and teaching medical science for which college was formed). But see Priv. Ltr. Rul. 8028004 (Mar. 26, 1980) (Tech. Adv. Mem.) (although conducted in part by students from universities, research by tax-exempt organization was primarily for benefit of commercial sponsor and only incidentally for education of university students).

38. McGovern, The Exemption Provisions of Subchapter F, 29 TAX LAw. 523, 524 (1976); see also Hansmann, The Rationale for Exempting Nonprofit Organizations from Corporate Income Taxation, 91 YALE L.J. 54, 58 n.17 (1981) [lhereinafter cited as Hansmann, The Rationale for Exempting Nonprofit Organizations from Corporate Income Taxation] ("[I]t appears that the exemption has been kept largely coextensive with the scope of the nonprofit sector primarily through the continual redefinition of the exemption to accommodate it to changes in the activities undertaken by nonprofits, and not because nonprofits tend to develop or survive only in industries in which the exemption has already been clearly established.").

39. All organizations must also fulfill several requirements to qualify for exemption under $\S$ $501(c)$ (3). First, the organization must satisfy the "organizational test" by limiting its purposes, in its charter, to one of more exempt objectives. Treas. Reg. $\S 1.501(c)(3)-1(b)(1960)$; see I.R. Manual 7751: ExEMPT ORGANIZATION HANDBOOK $\$ \S 340-370$. Second, the organization must satisfy the operational test" by engaging "exclusively" in activities that accomplish one or more exempt purposes. See I.R. Manual. 7751: Exempt Organization Handbook $\S \S 330-338$. Treas. Reg. $\S$ $1.501(c)(3)-1(c)(1)(1959)$, however, mitigates the strict requirement of $\S 501(c)(3)$ by providing that an organization will be regarded as "operated exclusively" for $\S 501$ (c)(3) purposes if it "engage primarily" in activities which accomplish its exempt purposes. And third, the organization must also ensure that none of its net earnings inure to the benefit of any private shareholder or individual. Treas. Reg. $\S 1.501(c)(3)-1(c)(2)$ (1959). Although these three requirements apply to all exempt organizations, they either presume or completely avoid grappling with the concept or meaning of 
"An organization is not organized or operated exclusively for one or more of the [exempt] purposes . . . unless it serves a public rather than private interest." 40 This requirement echoes the commonly held sentiment that the favorable tax treatment accorded charities is justified by the benefit the public obtains from their activities. ${ }^{41}$ In enacting the Revenue Act of $1938,{ }^{42}$ Congress expressly confirmed this view:

The exemption from taxation of money and property devoted to charitable and other purposes is based on the theory that the government is compensated for the loss of revenue by its relief from financial burdens which would otherwise have to be met by appropriations from other public funds, and by the benefits resulting from the promotion of the general welfare. ${ }^{43}$

Despite their general acceptance, however, phrases such as "public interest" and "general welfare" do not sufficiently distinguish between exempt and non-exempt activities. Nearly everything produced by the private industry-ranging from buildings and food to books and music-contributes to our welfare. Implicit in the commonly held rationale for exempting research universities from tax, therefore, are two intimately linked, though often overlooked, components: First, these organizations provide services that promote the public welfare; and second, these services would be undersupplied without exemption. ${ }^{44}$

Universities engaged in scientific research fulfill the two necessary components of exemption primarily by engaging in basic research that the private market is ineffective in providing. "Basic" or "fundamental" re-

"exempt."

40. Treas. Reg. § 1.501(c)(3)-1(d)(1)(ii), as amended by T.D. 6526, 1961-1 C.B. 186, 187.

41. See, e.g., Trinidad v. Sagrada Orden de Predicadores, 263 U.S. 578, 581 (1924) ("Evidently the exemption is made in recognition of the benefit which the public derives from corporate activities of the class named, and is intended to aid them when not conducted for private gain.").

42. Revenue Act of 1938, Ch. 289, 52 Stat. 447.

43. H.R. ReP. No. 1860, 75th Cong., 2d Sess. 19 (1938).

44. Certain services, which economists refer to as "public goods," are undersupplied because they do not respond well to private market forces, and the usual economic incentives to provide these good do not exist. One reason for this phenomenon lies in the fact that once "public goods" are supplied to one person, they are available to others at no additional cost, for one person's enjoyment of the services does not interfere with another's concurrent ability to enjoy them. Furthermore, once these services are provided to one person, others cannot be prevented from consuming them as well. To provide the optimal level of these services most efficiently, each individual should ideally contribute a sum equal to the value he places upon them. Individuals, however, have little incentive to pay for the cost of such services. One person's contribution is likely to be so proportionately small that it will not appreciably affect the amount of the services provided. Moreover, the individual will in any case be able to enjoy the services financed by others' contributions. If all individuals follow this logic, then little or none of the services will be supplied despite actual collective demand for them. The private market, therefore, is ineffective in providing certain services. See R. Musgrave \& P. Musgrave, Public Finance in TheORY AND PRACTICE 49-80 (2d ed. 1976); Hansmann, The Role of Nonprofit Enterprise, supra note 1 , at $848-49$. 
search has been described as "undirected research pursued solely for satisfying human curiosity and with no direct practical application intended or in mind." 15 In contrast, "applied" research has been described as an "undertaking carried on for exploitation or application in commercial or industrial fields." ${ }^{16}$ Universities are more likely to produce basic research than their proprietary counterparts ${ }^{47}$ because universities are at least partially free of the profit motive that forces the commercial enterprises to neglect research that does not promise reasonable returns within a relatively short time. ${ }^{48}$ As a result, universities have become the primary institution within our society for discovering new knowledge through basic or fundamental research. ${ }^{49}$ By exempting universities from tax, the Internal Revenue Code in effect spurs them to produce a product mix distinct from that of commercial enterprises.

The difference between "basic" research and research in the "public interest" as exempted by tax laws may, at first, seem negligible, but its importance becomes quite clear once it is recognized that the conditions necessary to promote basic and applied research are different. Many of the eventual applications of basic research results cannot be foreseen; it is essential that such results be disseminated as widely as possible. ${ }^{50}$ Moreover, scientists rarely make new discoveries without relying in part on the groundwork of others. ${ }^{81}$ The principles of free inquiry and open dissemination of ideas, therefore, are principles that must be upheld by the tax code if the advancement of fundamental knowledge is its main goal in exempting research organizations from tax.

45. Hearings before Ways and Means Committee, 85th Cong., 2d Sess., 1152 (1956) (statement of Dr. Clifford Furnas, Chancellor of University of Buffalo) cited in I.R. MANual 7751-18: EXEMPT ORGanization HaNDBOOK, $\S 37(89)(4)$.

46. Id.

47. Hansmann, The Rationale for Exempting Nonprofit Organizations from Corporate Income Taxation, supra note 38 , at 68.

48. Commercial enterprises exist primarily to seek optimum return on their investment. They also demand financial rewards commensurate with the risks they take. Their approach to research and development, therefore, is governed by the view that "research is a[n] . . . investment whose function is to provide eventual payoff in terms of a product . . . that will improve corporate performance." Peters \& Fusfeld, supra note 2, at 24. This narrow perspective limits the horizon of research undertaken, ignoring vital areas which may advance knowledge but do not promise an cventual product. See Bouton, supra note 2, at 121 (quoting Arthur L. Caplan, ethicist at the Hastings Center).

49. In 1981 universities carried out about $49 \%$ of the total basic research in the United States as compared to industry's $18 \%$. See Fusfeld, supra note 24, at 12. Profit-making corporations acting in the marketplace, on the other hand, are the chosen vehicles for turning new knowledge into useful products. Undoubtedly this simple dichotomy is not $100 \%$ accurate. Many commercial enterprises regularly engage in basic research, while numerous universities regularly do work directly concerned with producing products. There is, in fact, a continuous spectrum ranging from the extremely basic work in theoretical science to the most applied steps in developing a new product for a specific market. Nevertheless, universities tend to focus more on the former.

50. See Giamatti, supra note 12 , at 5 .

51. See Bok, supra note 19 , at 26 ("[Slince all scientific discoveries build upon existing knowledge, investigators must have access to the widest body of scientific work. . . ."). 
Basic research, naturally, is not the only undersupplied scientific activity. Applied research may fulfill the undersupplied service component of the rationale for exemption on, at least, three grounds. First, despite the potential for profit, commercial enterprises cannot be expected to cover the tremendous breadth of research that can be characterized as "applied." Second, due to the increasing complexity of advanced technology, it is difficult for any one company, or even one industry, to maintain the facilities and diversity of personnel necessary to develop the new technology and apply it to manufacturing. ${ }^{53}$ And third, in some fields, especially in the biotechnologies, the remarkably short innovation cycle may have obliterated any significant distinction between basic and applied research. ${ }^{\text {s4 }}$

Although commercial enterprises may rely on research universities to provide "applied" research that they themselves neglect, and the results of such applied research need not be disseminated to guarantee the continued development of basic research, the least intrusive yet effective way of promoting all undersupplied research is by subjecting research universities to a uniform requirement to disseminate research results. This is the absolute minimal condition necessary for promoting basic research, the primary undersupplied activity undertaken by universities. Moreover, because "basic" and "applied" research cannot easily be distinguished and research universities undertake both at the same time, a uniform dissemination requirement would have the benefit of avoiding unnecessary governmental intrusion into university research in an effort to distinguish basic from applied research.

\section{Current Status of the Law}

In failing to pinpoint basic research as the primary exempt "scientific" activity and to appreciate its implications, the tax provisions commit three fundamental mistakes. First, they fail to identify the essential condition for promoting basic research. Second, this mistake further blinds the provisions to the possible conflicts among exempt purposes-for example, between scientific and educational activities-of the nonprofit universities. And third, the overly broad definition of "scientific" undermines other tax provisions whose effective operation hinge on this definition. Each of these three mistakes will be analyzed in turn.

52. See Bouton, supra note 2, at 153.

53. See Press, supra note 28 , at 43.

54. See id. at 44 . 


\section{A. Definition of Scientific and Condition of Research}

The Treasury offers no definition of "scientific." Moreover, it provides that '[ $t$ ] de determination as to whether research is 'scientific' does not depend on whether such research is classified as 'fundamental' or 'basic' as contrasted with 'applied' or 'practical." simply emphasizes that " $a$ 'scientific' organization must be organized and operated in the public [as contrasted with private] interest."

Research will be regarded as "carried on in the public interest" only if one of three tests is met:

(a) [i]f the results of such research (including any patents, copyrights, processes, or formulae resulting from such research) are made available to the public on a non-discriminatory basis;

55. The regulations merely stress that scientific organizations must be organized and operated exclusively for public purposes. See supra note 40 . The regulations, however, do clarify that "scientific" is not synonymous with "research" so that organizations conducting research are not granted exemption under $\$ 501$ (c)(3) on that basis unless their activities are directed toward exempt purposes. Treas. Reg. $\S 1.501$ (c)(3)-1(d)(5)(i), as amended by T.D. 6525, 1961-1 C.B. 186, 187. Therefore, if the organization engages primarily in commercial business activities or serves private interests, it will not qualify for exemption even though its activities may fall within the popular meaning of the term "scientific." See, e.g., Universal Oil Prods. Co. v. Campbell, 181 F.2d 451, 464-65 (7th Cir. 1950) (exemption denied to organization conducting research into petroleum drilling where major oil companies receive results of research which would directly and substantially benefit their commercial business endeavors).

The regulations further exclude from the definition of "scientific" those "activities of a type ordinarily carried on as an incident to commercial or industrial operations" such as "the ordinary testing or inspection of materials or products or the designing or construction of equipment, buildings, etc." Treas. Reg. $\$ 1.501$ (c)(3)-1(d)(5)(ii), as amended by T.D. $6525,1961-1$ C.B. 186, 187. The court in Midwest Research Inst. v. United States, 554 F. Supp. 1379 (W.D. Mo. 1983), adopted a restrictive interpretation of both "ordinary testing" and "designing or construction." It observed that all exempt research designed to develop an industry could "conceivably be conducted by a particular research . . . department of a large business or industrial enterprise." Id. at 1386 (footnote omitted); see also id. at 1386 n.11. The court also stated that if the phrase "ordinary testing" was not given a restrictive interpretation, "serious questions [would be] raised regarding the validity of this portion of the regulation, given its apparent inconsistency with the statute and the legislative history." Id. at $1386 \mathrm{n} .12$. In Rev. Rul. 68-373, 1968-2 C.B. 206, 207, the IRS adopted a broader interpretation of the regulations. It denied exemption to an organization that engaged in testing drugs for conformity with Food and Drug Administration requirements because the research activity was incidental to the commercial operation of pharmaceutical companies that pay for the testing services. The fact that the research results are available for publication in various journals does not affect the organization's commercial stature. See Monroc, Collaboration Between Tax-Exempt Research Organizations and Commercial Enterprises-Federal Income Tax Limitations, 62 TAxes 297, 300-03 (1984) (distinguishing above interpretations of the regulations); see also Kertz, supra note 5, at 75 ("The primary rule is that where testing is carried on as part of a commercial operation, the organization which does the testing does not qualify as a Code section 501(c)(3) exempt organization.") (footnote omitted).

56. Treas. Reg. $\S 1.501$ (c)(3)-1(d)(5)(i), as amended by T.D. 6525, 1961-1 C.B. 186, 187; see, e.g., Dumaine Farms v. Commissioner, 73 T.C. 650, 665-66 (1980) ("The regulations do provide that practical or applied research . . . may be just as scientific as fundamental or theoretical research which advances basic science."). Accordingly, it appears that the term "scientific," as used by § $501(c)(3)$, has been given a broad meaning; its limits seem dictated primarily by the exclusion of "activities of a type ordinarily carried on as an incident to commercial or industrial operations." Treas. Reg. $\S 1.501$ (c)(3)-1(d)(5)(ii), as amended by T.D. 6525, 1961-1 C.B. 186, 187.

57. Treas. Reg. $\S 1.501(\mathrm{c})(3)-1(\mathrm{~d})(5)(\mathrm{i})$, as amended by T.D. 6526, 1961-1 C.B. 186, 187. 
(b) [i]f such research is performed for the United States, or any of its agencies or instrumentalities, or for a State or political subdivision thereof; or

(c) [if] such research is directed toward benefiting the public. ${ }^{58}$

The subdivision (c) test, which seems simply to restate the public interest requirement, has caused the most controversy. The Treasury has defined "directed toward benefiting the public" only by giving four examples $^{59}$ of research that satisfy the requirement and two examples ${ }^{60}$ of research that do not. These examples provide little guidance. ${ }^{61}$

Despite the extensive interpretation of the subdivision (c) test, the majority of rulings ignores a vital question: Whether the results of research

58. Treas. Reg. $\$ 1.501(\mathrm{c})(3)-1(\mathrm{~d})(5)(\mathrm{iii})(\mathrm{a})$ to $1(\mathrm{~d})(5)(\mathrm{iii})(\mathrm{c})$, as amended by T.D. 6525, 1961-1 C.B. 186, 187. The IRS gives no guidelines as to the degree of public availability required. Publication of the research results, however, will certainly suffice. See infra note 59.

59. Treas. Reg. $\S 1.501$ (c)(3)-1(d)(5)(iii)(c)(1)-(4), as amended by T.D. 6525, 1961-1 C.B. 186, 187 , furnishes four examples of scientific research that will be considered as "directed toward benefiting the public, and, therefore,. . .be regarded as carried on in the public interest." They are:

(1) Scientific research carried on for the purpose of aiding in the scientific education of college or university students; (2) scientific research carried on for the purpose of obtaining scientific information, which is published in a treatise, thesis, trade publication, or in any other form that is available to the interested public; (3) scientific research carried on for the purpose of discovering a cure for a disease; or (4) scientific research carried on for the purpose of aiding a community or geographical area by attracting new industry to the community or area or by encouraging the development of, or retention of, an industry in the community or area.

Id. (emphasis added).

To meet the publication test prescribed by example (2), the Treasury requires "adequate and timely" publication. Rev. Rul. 76-296, 1976-2 C.B. 141, 142. "Some public disclosure beyond that which flows naturally from the issuance of a patent is required. In addition, the publication must disclose substantially all of the information concerning the results of the research which would be useful or beneficial to the interested public." Id. Moreover, "[a]lthough the timing of the publication may vary depending upon the circumstance, the publication must be reasonably prompt because the public disclosure as an addition to the body of useful scientific knowledge is the reason for considering the activity as directed toward benefiting the public." Id. at 142-43. Based on these requirements, the Treasury held that "publication may be withheld until a patent application thereon has been prepared and filed, provided that such period shall not exceed 120 days." Priv. Ltr. Rul. 8501082 (Oct. 10, 1984). The Treasury has also held that because the purpose of the publication requirement is "not to place an extra burden upon the exempt organization, but only to assure that by some means or other the information reaches the interested [sic] public," there is no requirement that the publication be undertaken by the organization performing the research. Priv. Ltr. Rul. 8028004 (Mar. 26, 1980) (Tech. $\Lambda$ dv. Mem.) It is sufficient that the commercial sponsor distributes the results of the study to business enterprises and state agencies. $I d$.

60. Treas. Reg. $\S 1.501$ (c)(3)-1(d)(5)(iv)(a)-(b), as amended by T.D. 6525, 1961-1 C.B. 186, 187-88. The organization "will not be considered organized and operated for the purpose of carrying on research in the public interest if:

(a) Such organization will perform research only for persons which are (directly or indi-

rectly) its creators and which are not described in section 501(c)(3), or

(b) Such organization retains (directly or indirectly) the ownership or control of more than an insubstantial portion of the patents, copyrights, processes, or formulae resulting from its research and does not make such patents, copyrights, processes, or formulae available to the public.

Id. (emphasis added).

61. See Monroe, supra note 55, at 303-06 (difficulty of extracting "meaningful or consistent principles" from six examples). 
must be generally available to benefit the public or whether they need be published only when explicitly prescribed. ${ }^{82}$ The only rulings that deal explicitly with this publication requirement are vague and inconsistent. ${ }^{\text {es }}$ The prevailing view requires publication only when explicitly prescribed. ${ }^{64}$ The only restriction to this permissive treatment of collaborative research is that to qualify as "scientific" research under section 501(c), the research activities may not be of a type "ordinarily carried on as an incident to commercial or industrial operations." ${ }^{\circ 5}$ Thus the subdivision (c) test, through its latitude, excuses many important university-industry collaborations from reporting requirements, even though the research results are disclosed and assigned exclusively to the commercial sponsors, who exploit the results for profit.

Other Treasury regulations attempt, with limited effectiveness, to curb potential subdivision (c) abuses. For example, an entity will not qualify as a tax-exempt scientific organization under section 501(c)(3) if it "retains (directly or indirectly) the ownership or control of more than an insubstantial portion of the patents, copyrights, processes, or formulae resulting from its research and does not make such patents, copyrights, processes, or formulae available to the public."Bs The vagueness of this characterization, however, severely limits the IRS's ability to govern the extent to

62. On two occasions the Treasury explicitly requires the dissemination of research results. The subdivision (a) test of research "carried on in the public interest" requires that the results be "made available to the public on a nondiscriminatory basis." Treas. Reg. $\$ 1.501$ (c)(3)-1(d)(5)(iii)(a), as amended by T.D. 6525, 1961-1 C.B. 186, 187 (emphasis added). See supra note 59 and accompanying text. And example (2) of the four examples of scientific research that will be considered as "directed toward benefiting the public" requires that the results be "published . . . in any ... form that is available to the interested public." Treas. Reg. $\$ 1.501$ (c)(3)-1(d)(5)(iii)(c)(2), as amended by T.D. $6525,1961-1$ C.B. 186, 187 (cmphasis added). See supra note 59 and accompanying text. The regulations do not give any guidance as to whether all research must comply with the dissemination requirement for the organization to be exempted from taxation.

63. The only rulings that deal explicitly with the publication requirement are vague and inconsistent. See, e.g., Priv. Ltr. Rul. 8217066 (Jan. 27, 1982) (broad language requiring publication if scientific research is to be considered "in the public interest"). In a number of cases, the research activities undertaken are example (2) activities which already require publication. See supra note 59; see also Ltr. Rul. 8217066 (Jan. 27, 1982) (primary purpose of organization is to conduct fundamental medical and scientific research). In the majority of the cases publication was already made. The Treasury, although it used the fact of publication as some proof of an organization's public function, never explicitly addressed the publication requirement. See, e.g., Rev. Rul. 76-455, 1976-2 C.B. 150; Rev. Rul. 71-506, 1971-2 C.B. 233; Rev. Rul. 69-526, 1969-2 C.B. 115.

The only case dealing explicitly with the publication requirement held that the separate publication provision in example (2) rebutted the notion that the research in example (4) had to be published. Midwest Research Institute v. United States, 554 F. Supp. 1379, 1390 (W.D. Mo. 1983). See supra note 59; see also Monroe, supra note 55, at 304, 304 n.61 (certain research activities need not be published or made available to public).

64. See supra note 71 .

65. Treas. Reg. $\$ 1.501$ (c)(3)-1(d)(5)(ii), as amended by T.D. 6525, 1961-1 C.B. 186, 187. For definition and interpretation of the phrase "activities of a type ordinarily carried on as an incident to commercial or industrial operations," see supra note 55.

66. Treas. Reg. \& 1.501(c)(3)-1(d)(5)(iv)(b), as amended by T.D. 6525, 1961-1 G.B. 186, 187188 (emphasis added). 
which an exempt organization may permit its commercial sponsor to obtain research results.

The regulation contains two debilitating ambiguities. ${ }^{67}$ First, what is the meaning of "retain (directly or indirectly)"? Interpreted broadly, "indirect" retention occurs when research results are licensed (as contrasted with assigned) to the commercial sponsor. ${ }^{68}$ Paradoxically, however, this interpretation would not prohibit arrangements which disclose and assign research results exclusively to the commercial sponsor. Read literally, "indirect" retention occurs only if the exempt organization has direct or indirect proprietary interest in the commercial sponsor. ${ }^{69}$ Neither the regulations nor the Service, however, provide any guidance as to the nature and extent of proprietary interest necessary to trigger this provision. This regulation may simply mean that the commercial sponsor must make the patents, copyrights, processes, or formulae available to the public only if the commercial sponsor is owned ${ }^{70}$ by the exempt university. Both the broad and literal readings, therefore, result in an indefensible disparity. The universities that retain the patents, copyrights, processes, or formulae are required to make them public although the commercial sponsors who are granted the same rights are not bound by the public availability requirement.

The second critical ambiguity is the meaning of "available to the public." The regulations provide that the research results will be considered to have been made "available to the public" even if the rights to the use of patents, copyrights, processes, or formulae are granted exclusively to one or more persons, so long as the granting of such exclusive rights is the only practicable manner in which the results can be used to benefit the public. ${ }^{71}$ This provision may be interpreted to reinforce the broad reading of "indirect retention" that permits the universities to assign tax-exempt research results to their commercial sponsors. Not only are the results assignable, but under this provision they may be assigned exclusively. The

67. There is also a third ambiguity regarding this example of a non-exempt organization, namely the meaning of "more than. . insubstantial." Treas. Reg. $\S 1.501$ (c)(3)-1(d)(5)(iv)(b), as amended by T.D. $6525,1961-1$ C.B. 186, 187. There are no guidelines for determining the meaning of this vague yet important phrase.

68. License, in contrast with assignment, merely gives the commercial sponsor the right to manufacture and sell the patent and not ultimate control or ownership of it.

69. See Monroe, supra note 55, at 305 (if exempt organization has no ownership interest in commercial sponsor, no requirement that commercial sponsor disseminate research results).

70. Ownership presumably will consist of $51 \%$ or more of the shares in the commercial enterprise.

71. Treas. Reg. $\S 1.501$ (c)(3)-1(d)(5)(iv)(b), as amended by T.D. 6525, 1961-1 C.B. 186, 188 (1984), provides,

although one person is granted the exclusive right to the use of a patent, copyright, process, or formula, such patent, copyright, process, or formula shall be considered as made available to the public if the granting of such exclusive right is the only practicable manner in which the patent, copyright, process, or formula can be utilized to benefit the public.

No cases or rulings have offered a sensible reading of this troublesome provision. 
vagueness of the regulatory language, therefore, leaves uncorrected the potential for abuse of section 501(c).

\section{B. Multiple Basis of Exemption}

In addition to failing to identify the dissemination requirement necessary to promote basic research, by relying primarily upon the public interest requirement in defining the exempt purposes, the present tax provisions fail to recognize that the promotion of different exempt activities may require different, and even conflicting, conditions. As a result, the same activities that qualify as "scientific" may at present also be exempt under other independently defined exempt categories such as "educational" and "charitable." ties often fulfills the required instructional aspect of the "educational" purpose; ${ }^{73}$ universities, therefore, may easily elude the dissemination requirement of the "scientific" purpose by relying on this alternative basis for exemption. Consequently, research universities may presently ignore the entire section of the regulations on "scientific" activities. Undersupplied research is hampered under this tax scheme because universities constitute our society's primary institution for undertaking basic research. ${ }^{74}$ The unfocused leniency of the multiple bases for exemption, therefore, must be restricted to fulfill the Code's intent of promoting "scientific" research.

\section{Tax on Unrelated Business Income}

Due to their multiple bases for exemption, research universities are seldom concerned about the effect of their research activities on their qualification for exempt status under the "scientific" rubric. ${ }^{75}$ Not qualifying as "scientific" under section 501(c)(3) may, nevertheless, subject the research activities to the unrelated business income tax. ${ }^{78}$ Research universities,

72. See supra note 37 and accompanying text.

73. For a definition of "educational" organizations, see supra note 36. For discussion of "scientific" activities that also qualify as "educational," see supra note 37.

74. See supra note 49 and accompanying text.

75. See Kerty, supra note 5 , at 71-72.

76. I.R.C. \& 513 (1982) taxes exempt organizations on income from:

any trade or business the conduct of which is not substantially related (aside from the need of such organization for income or funds or the use it makes of the profits derived) to the exercise or performance by such organization of its charitable, educational, or other purpose or function constituting the basis for its exemption ....

Thus the activity itself must further the exempt purposes. It is not sufficient to examine the use of the income generated by the activities.

Prior to 1950, the Supreme Court established that the destination of income, rather than its source, was the controlling test in determining the right to exemption. See, e.g., Trindad v. Sagrada Orden de Predicadores, 263 U.S. 578, 581 (1924) (test for determining qualification for tax exemption looks to application of organization's income and not to source from which it is derived). Congress overruled 
therefore, are and should be sensitive to the determination of whether an activity is "scientific." Since the unrelated business income tax provisions are the primary mechanisms that trigger the effective operation of the restrictions on exemption, whatever their purpose, they should not undermine the definition or requirements of "scientific." Unfortunately, this is precisely what the provisions manage to do.

The regulations provide a three-part test for determining whether income of an otherwise exempt organization would be subject to taxation as "unrelated business income." Such income is taxable only if (i) the income comes from a trade or business; ${ }^{77}$ (ii) the trade or business is regularly carried on by the organization; $;^{78}$ and (iii) the conduct of the trade or business is not substantially related to the organization's performance of its exempt functions. ${ }^{79}$ In the case of a research university, the third test of whether an activity is substantially related to an exempt function will generally depend on whether the activity is scientific research within the meaning of $\S 501(c)(3) .{ }^{80}$ Because research activities not qualifying as

the designation test by imposing the unrelated business income tax in the Revenue Act of 1950, Pub. L. No. $81-814, \S \S 301,331,64$ Stat. 906, 947-53, 957-59 (codified at 26 U.S.C. $\$ \S 502-514$ (1976), a tax later expanded in the Tax Reform Act of 1969, Pub. L. No. 91-172, § 121, 83 stat. 487, 536549 (codified as amended in IRC $\S \S 511-514$ (West Supp. 1985) and scattered sections of 26 U.S.C.).

As the legislative history clearly indicates, the tax was intended primarily, though not exclusively, to prevent exempt organizations from gaining an unfair competitive advantage over taxpayer enterprises. See, e.g., S. Rep. No. 2375, 81st Cong., 2d Sess. 28, reprinted in 1950 U.S. Code Cong. \& Ad. News 3053, 3081: "The problem at which the tax on unrelated business income is directed is primarily that of unfair competition. The tax-free status of section 501 organizations enables them to use their profits tax-free to expand operations, while their competitors can expand only with the profits remaining after taxes." Several commentators have reviewed the events leading to the enactment of this law. See Bittker \& Rahdert, The Exemption of Nonprofit Organizations from Federal Income Taxation, 85 YAl. L.J. 299, 301-16 (1976); Myers, Taxing the Colleges 38 CoRnel. L.Q. 368, 368-377 (1953).

77. Treas. Reg. § 1.513-1(b), as amended by T.D. 7392, 1976-1 C.B. 162, 168. Despite the repeated references in the legislative history of the unrelated business income tax to the congressional intent to prevent unfair competition, $\S 513$ is silent on this point. The I.R.S. maintains that the potential for unfair competition is merely one factor to consider in determining whether an activity constitutes a trade or business under $\S 513$. See, e.g., Clarance LaBelle Post No. 217 v. United States, 580 F.2d 270, 273 (8th Cir. 1978), cert. denied, 439 U.S. 1040 (1978). The circuits have split on whether an activity must pose a threat of unfair competition in order to be considered a trade or business. Compare Carolinas Farm \& Power Equipment Dealers Association v. United States, 699 F.2d 167, 170 (4th Cir. 1983) (as.matter of law, activity is trade or business if conducted for production of income from sale of goods or the performance of services) with Louisiana Credit Union League v. United States, 693 F.2d 525, 541 (5th Cir. 1982) (possibility of unfair competition does not control; rather, test is intent to earn profit).

78. Treas. Reg. $\$ 1.513-1$ (c) (1967). The determining factors of this second test are "the frequency and continuity with which the activities of the income are conducted and the manner in which they are pursued."

79. Treas. Reg. $\S 1.513-1($ d), as amended by T.D. 7896, 1983-1 C.B. 108, 110-111 (activity is not "substantially related" to organization's exempt purpose or purposes unless activity "contributes importantly" to accomplishment of its exempt purposes). Under this test, the relationship between activity and purpose must be a "causal" one. The size and extent of the activities in relation to the nature and extent of the exempt purposes must also be considered.

80. If an activity is not scientific research carried on in the public interest and is not within some other exempt purpose under $\S 501(\mathrm{c})(3)$, the activity will generally not be viewed as substantially 
"scientific" may be subjected to the unrelated income tax, the shortcomings of section 501(c)(3), discussed above, distort the determination of what constitutes unrelated business income.

An activity not substantially related, however, will not necessarily be subjected to the unrelated business income tax. It may still fail the first and second tests by not rising to the level of a trade or business being regularly carried on. Accordingly, the unrelated business income tax may exempt income derived from research that does not fulfill the public interest requirement of both section 501(c)(3) or the general rationale for exempting nonprofit organizations from tax.

Income may further be excluded from the tax by one of several statutory modifications to the definition of unrelated business income. ${ }^{81}$ The modifications exclude income from certain kinds of research, including "in the case of a college, university, or hospital . . . all income derived from research $^{82}$ performed for any person . . . ."83 This broad modification in effect excludes most research activities of a college or university from tax, with the single qualification that such research may "not include activities of a type ordinarily carried on as an incident to commercial or industrial operations."84

These modifications to the definition of "unrelated business taxable income" are inconsistent even with the Code's vague purpose of exemption on two grounds. First, the singular requirement that research cannot be incident to commercial or industrial operations exempts from taxation re-

related to an exempt function and will be subjected to the unrelated business income tax.

81. I.R.C. $\$ 512(b)(1)-(12)$ (1967 and West Supp. 1985). The excluded items include interest, dividends, rents and royalties.

82. The legislative history, convincingly interpreted by one commentator, shows that Congress intended a broad meaning of the word "research": It "would include not only fundamental research but also applied research such as testing and experimental construction and production." Kertz, supra note 5 , at 79-80.

83. I.R.C. $\S 512(b)(8)(1982)$. In several rulings the I.R.S. has found that income from research is excluded from unrelated business taxable income pursuant to $\S 512(b)(8)$ because it is conducted by a college, university, or hospital. See, e.g., Priv. Ltr. Rul. 7936006 (May 23, 1979) (Tech. Adv. Mem.) ("E]ven if the research was not so related to the exempt purposes of the college, the income derived from the research would fall within section 512(b)(8)."). The I.R.S., however, has refused to apply $\$ 512(b)(8)$ to the income of an organization which claimed it was merely an extension of universities with which it worked closely. See, e.g., Priv. Ltr. Rul. 8409055 (Nov. 29, 1983) ("[A]fter considering all the facts and circumstances, including your separate incorporation, separate purposes, separate facilities and separate operation, we have concluded that you are not an extension of $\mathrm{M}$ [a university]. . . . As a consequence... you are not a "university."').

84. Treas. Reg. $\S 1.512(b)-1(f)(4)$, as amended by T.D. 6939, 1968-1 C.B. 274, 282. Compare this provision with Treas. Reg. 1.501(c)(3)-1(d)(5)(i), as amended by T.D. 6939, 1968-1 C.B. 274, 282. See supra note 55. The two provisions are identical and have been similarly interpreted. Consequently, the rulings under one provision have been cited as authority under the other provision. See, e.g., Priv. Ltr. Rul. 7852007 (Sept. 13, 1978). Therefore, if research qualifies as an activity of a type not ordinarily carried on as an incident to commercial or industrial operations, then any income from the research will be excluded from "unrelated business taxable income" under one of these exclusions. 
search that is not "carried on in the public interest." Second, the modifications exempt income generated by "unrelated" research.

\section{University Versus GOVERnMental ReSEarch}

The identification of basic research as the primary scientific activity undersupplied permits a more precise formulation of what ought to constitute exempt activities. Knowing the task to be performed, however, leaves unanswered the further question of who ought to perform it. We need to understand why research universities are better than other alternatives, particularly the government, in providing basic research, in order to better tailor amendments to the existing tax provisions.

Direct governmental undertaking of basic research is more pervasive than often imagined. Many private universities, such as Columbia and Harvard, in fact, owe their origins and early support to the public sector. ${ }^{85}$ And since World War II, the sponsorship of research at American universities has been dominated by federal funding, a trend which will most likely continue. ${ }^{86}$ Finally, the prominence of private, nonprofit universities is a phenomenon unique to the United States. Past and present reality, therefore, presses us to uncover a more complete explanation for exempting research universities from tax: It asks why, despite the viability of direct governmental sponsored research, we have persistently turned to nonprofit organizations.

Numerous efficiency arguments can be made in support of our historical reliance. By virtue of their relative independence, research universities can more readily adjust the standards and directions of research to new scientific developments. Correspondingly, such independence is free of an expectedly sluggish and disproportionately costly bureaucracy. ${ }^{87}$ The particular tasks performed by the universities and the institutional loyalty generated by these institutions may also encourage the application of private wealth beyond, some would argue, what the individual philanthropist would have paid in tax. ${ }^{88}$ Finally, in universities, research and training are inextricably linked. The universities began and still exists mainly to teach. Although they have become our society's primary institution for discovering new knowledge, university research has always been coupled

85. L. Salamon \& A. Abramson, The federal Budget and the Nonprofit Sector, $37-38$ (1982).

86. In contrast, since 1965 , the industrial contribution to academic research has remained between three and four percent. This amount represents about one-half of one percent of total national research and development spending, which was about $\$ 85$ billion in $\mathbf{1 9 8 3}$. Consequently, the collaboration between universities and commercial enterprises must be put in the proper perspective. See Press, supra note 28, at 41-42; Fusfeld, supra note 24, at 12-13.

87. See Hansmann, The Role of Nonprofit Enterprise, supra note 1, at 895.

88. See, e.g., L. SalAmon \& A. AbramSon, supra note 85, at 35. 
with teaching and training. The dual functions of research universities make them a more attractive choice and have thus diverted the difficult choice between supporting universities and supporting federal laboratories.

Acknowledgedly, some research will always be performed by universities; historical contingency, however, cannot tell us how much and what sort-especially when equally valid efficiency reasons argue against depending on the universities. Due to its taxing power, the government possesses more reliable access to capital. ${ }^{89}$ In addition, an exemption from income taxation is at best a crude mechanism for subsidizing undersupplied goods and services. ${ }^{00}$ To guarantee the continual development of undersupplied research, therefore, the government may increasingly need to absorb the university research originally funded by exemption.

The indeterminacy of efficiency arguments ought not be surprising, for it highlights the importance of certain non-efficiency values that have developed during our continual support of nonprofit universities, at least one of which has been clearly expressed by judges and commentators alike. According to them, "providing public goods and services through the private, rather then the public, sector is inherently desirable in a pluralistic society." of nonprofit universities that has emerged in our impersonal and alienating society is that the universities have become communities of farreaching bonds and sources of identity. This emotional attachment is most clearly exhibited by the unusual loyalty and pride university graduates lavish on their alma mater.

Despite these important non-efficiency values, as the pressure of money multiplies, the spirit of research universities may well dissipate in the growing labyrinth of industrial and governmental ties. To avoid this all too likely natural course of events, the government must in the distant future assess the importance of independent nonprofit universities. This Note does not pretend to know what the government should eventually do, if it can do anything at all. It, however, does want to point out the problem and issues so that when the time to decide reaches us, we will at least know what is at stake. In the meantime, this Note suggests that the universities should have every chance of making the choice of whether to continue their independence themselves. This choice, however, does not come from sloppy and overly generous exemption provisions which actually un-

89. See Hansmann, Role of Nonprofit Enterprise, supra note 1, at 894.

90. See Hansmann, The Rationale for Exempting Nonprofit Organizations from Corporate Income Taxation, supra note 38 , at 75.

91. See Note, The Participation of Charities in Limited Partnerships, 93 YALE L.J. 1355, 1358 (1984); see also Green v. Connally, 330 F. Supp. 1150, 1162 (D.D.C. 1971) 
dermine the promotion of exempt activities. Rather, the government should be explicit and precise on the qualifications of exemption. Once the minimal conditions necessary to promote the exempt activities are established, however, the exemption provisions should be as generous as possible to allow the research universities to perform their unique functions. It is with these presumptions that this Note approaches the current vagueness of the tax provisions.

\section{Proposed Amendments to the Internal Revenue Code}

A survey of the Code and regulations indicates that universities may elude the requirement to disseminate research results while retaining the exempt status of their sponsored research. They may also engage in activities unrelated to their exempt purpose and of no benefit to the general welfare while escaping the unrelated business income tax. The Code thus violates the rationale for exempting nonprofit universities from tax. This rationale suggests that several amendments to the existing tax provisions are necessary.

With regard to the basic tax exemption, the Code needs to identify the undersupplied goods provided by research universities and establish the conditions necessary to promote such goods. In addition, the Code must ensure that the exempt activities benefit the public welfare. Finally, the Code should employ the unrelated business income tax as a means of encouraging the universities to supply undersupplied services.

\section{A. Proposal to Amend Section 501(c)}

Since university-based research is concerned primarily, though not exclusively, with the advancement of fundamental knowledge, the promotion of basic research should constitute the Internal Revenue Code's primary objective. On a practical level, therefore, there is a coincidence of concerns between the academic community and the Internal Revenue Code. ${ }^{22}$ But tax laws cannot and should not regulate the direction of scientific research performed by the universities. ${ }^{\boldsymbol{\theta}}$ Rather, universities themselves should es-

92. For the two main dangers perceived by the academic community regarding the recent upsurge of collaborations between universities and commercial enterprises, see text accompanying notes 12-23.

93. The I.R.C. constitutes an important mechanism in our society for policing nonprofit organizations. See supra note 11. Despite this fact, the role of the I.R.C. in regulating the collaborations between universities and commercial enterprises is necessarily limited to and governed by its rationale for their exemption. The regulations correctly assume that applied research may fulfill both compo.nents of the rationale for exempting nonprofit organizations from tax. See supra notes 52-54 and accompanying text. They also correctly assume that a research university may engage in undersupplied basic and applied research at the same time. See supra note 49 . Consequently, undersupplied research cannot be readily distinguished. Professor Hansmann proposes that all patentable research results be treated as deriving from nonexempt activities. Interview with Henry Hansmann, Professor of Law, Yale Law School, in New Haven (Mar. 8, 1985). In fields such as biotechnologies where the 
tablish guidelines to decide the desirability of engaging in a given piece of research. Unlike the direction of research, however, the use of research results may be effectively policed by the tax laws so as to justify their exemption from tax.

\section{Public Availability of Scientific Research}

Since most research universities are concerned primarily with the advancement of fundamental knowledge, and since "basic" research cannot be easily distinguished from "applied" research, all research activities engaged in by universities and other basic research organizations must be subjected to an effective dissemination requirement so that the vital objective of advancing fundamental knowledge will not be jeopardized. The highly ambiguous language of the current Treasury regulation, ${ }^{84}$ which requires that results of certain scientific research be made available to the public in order for the research organization to qualify for tax exemption under $\S 501(\mathrm{c})(3)$, should be amended to extend to all scientific research performed by colleges and universities. ${ }^{95}$

Educators may respond that this proposed amendment will force scholars to publish research results that do not merit the time and money that publication demands. ${ }^{96}$ The argument that this would constitute an infringement of academic freedom mistakes the intent of the Internal Revenue Code. The Code is intended to promote academic freedom only to the extent necessary to promote basic research. If scholarly freedom is infringed, it will be because of the scholar's decision to collaborate with industry. ${ }^{97}$

The unrestrained ability of universities and scientists to exchange research results promptly is essential to the health of individual institutions and the scientific community which they comprise. However, because unpatented, unmanaged, and unassignable uses of new developments may fail to attract necessary development capital, public interest is sometimes best served by timely protection of inventions. ${ }^{88}$ Therefore, the publication

innovation cycle is remarkably short, however, the lines between basic knowledge and its application are blurred. Basic research often provides patentable solutions to industry's problems. See Low, supra note 2 , at 68 . The impossibility of distinguishing undersupplied from other research suggests that the I.R.C. should let the universities regulate the direction of research themselves.

94. Treas. Reg. $\S 1.501$ (c)(3)-1(d)(5)(iii), as amended by T.D. 6525, 1961-1 C.B. 186, 187.

95. The extent and degree of dissemination required should vary depending on the circumstances. The present rulings regarding the publication test are adequate. See supra note 59.

96. This discussion is based on the author's interview with Robert Bickerton, Director of the Office of Cooperative Research of Yale University, in New Haven (Nov. 26, 1984).

97. A reasonable and flexible dissemination requirement should mitigate this infringement. See supra notes 59, 95. Morcover, university researchers are already subjected to extensive reporting requirement as a condition for receiving federal grants.

98. Interview with Robert Bickerton, supra note 96. See Kitch, The Nature and Function of the Patent System, 20 J.L. \& EcoN. 265 (1977) (patent system increases output from resources used for 
requirement should not stipulate that research results be disseminated immediately. Reasonable time before publication should be allowed for universities or their commercial sponsors to secure patents or other protections. ${ }^{99}$

Patenting the results of university research is compatible with the university's role as a center of investigation and dissemination of knowledge. ${ }^{100}$ Although the patent system confers exclusive rights, its purpose is to disclose the invention to the public. Patents restrict the use and sale of the invention, not its disclosure. ${ }^{101}$ Patenting does not delay the dissemination of knowledge for more than a few months. ${ }^{102}$

\section{Ownership and Licensing of Patents}

\section{a. Ownership of Patents}

One commentator has argued that the federal government should be the beneficiary of research it has helped to finance. According to this view, the patents developed from tax-exempt research should be transferred to the government which, in turn, would spend the proceeds from the patents to benefit the public generally. ${ }^{103}$ This policy, however, would simply discourage the universities from developing the patents, thereby unnecessarily inhibiting technology transfer.

A better way of encouraging the development and commercial use of patentable discoveries would be to permit the universities to take title to inventions arising from commercially sponsored research and to share in the profit they generate. This incentive would induce universities to identify patentable discoveries in their laboratories more aggressively and thus speed the translation of knowledge into useful products. ${ }^{104}$

In addition, to ensure that the public reaps the potential benefits from

technological innovation).

99. See supra note 59 .

100. See Lachs, University Patent Policy, 10 J.C. \& U.L. 263, 264-68 (1983-84) (university patent rights should be vigorously asserted).

101. See id. at 264.

102. See id. Furthermore, availability of patênts rights will not necessarily turn researchers away from basic research to short-term projects which promise immediate commercial reward. See id. at 265-66. Patent proceeds can be divided between the university and the researcher so as not to allow the inventor a profit large enough to take him away from projects of greater intellectual interest. For an example of a recommended formula for the division of royalty income, see Yale Report, supra note 18 , at $11-12$.

103. This discussion is based on the author's interview with Professor Hansmann, supra note 93.

104. See Bok, supra note 19 , at 30 (patents induce universities to identify patentable discoveries more aggressively); of. Patent and Trademark Laws, Pub. L. No. 96-517, § 6(a), 94 Stat. 3019, 3020-22 (1980) (to encourage commercialization of innovative ideas developed as result of federal sponsorship of university and industry-based R\&D projects, Act permits universities, nonprofit firms and small business to elect to take title to inventions arising from federally funded R\&D activities). Guidelines under Pub. L. No. 96-517 are issued in Patents-Small Firms and Nonprofit Organizations, Office of Management \& Budget Circular No. A-124, 47 Fed. Reg. 7556 (1982). 
exempt research, the Code should be amended ${ }^{105}$ to prohibit commercial sponsors from obtaining ownership of patents. ${ }^{108}$ An exclusive license to a patented invention usually will be as effective to the commercial sponsor as outright title to the patent. Moreover, such a prohibition would prevent the universities from assigning their most effective mechanism for policing the use of research results by their commercial sponsors. ${ }^{107}$

\section{b. Licensing of Patents}

Ideally universities should grant non-exclusive licenses to ensure wide access to research innovations and to minimize the risk of investing commercial enterprises with monopoly power. Often, however, companies need the protection afforded by an exclusive license to assume the cost and the risk of commercializing an invention. ${ }^{108}$ The regulations, therefore, should be amended to permit universities to grant limited-term exclusive licenses.

\section{Patent Policy and the Public Good}

There may be no inherent conflict between the patent system and the goals of academic science. Still, in order to benefit the general public, the university or commercial enterprise holding the patent or license should be required not only to make its knowledge public, but also to use such knowledge. It is not uncommon for commercial enterprises to obtain exclusive licenses purely to gain competitive advantage. The businesses want to stop their competitors from using the new knowledge, yet have no intention of commercializing the discovery. In order to maximize the benefit to the public welfare of subsidized research, universities must be obliged to grant the use of their inventions; commercial enterprises must, in turn, be obliged to develop and market them effectively.

Subdivision (5)(iii) should, therefore, be amended to require the effective use of the patents or licenses resulting from such research. This provision should require reasonable steps to commercialize the patents or licenses discovery within a reasonable number of years from the date of issuance of a patent or termination of any research program. Although the

105. Treas. Reg. $\S 1.501$ (c)(3)-1(d)(5)(iv)(b), as amended by T.D. 6525, $1961-1$ C.B. 186, 187-88, which describes an example of a non-exempt organization, should be repealed.

106. Patent ownership is less of an issue than the rights and conditions for licensing the product. See David, The University-Academic Connection in Research: Corporate Purposes and Social Responsibility, 64 J. Pat. OfF. Soc'y 209, 218 (1982).

107. By retaining ownership of patents, universities possess a stronger bargaining position to ensure that the licensee develops and exploits the license with due diligence.

108. See Bok, supra note 19 , at 31 (failure to grant exclusive licenses was major reason for lack of success in exploiting federal government held patents). 
Service cannot evaluate an organization's good faith in every case, it should have the authority to discipline gross abuses.

\section{The Primary Basis for Exemption}

Universities engaged in scientific research may also qualify as "educational" organizations and thereby avoid the dissemination requirement for "scientific" activities since the regulations emphasize the instructional aspect of education. ${ }^{109}$ In order to preserve the conditions necessary to promote basic research, the Code should be amended to limit the research universities' privilege to rely on their multiple bases for exemption. The Code should presume that collaborative research activities undertaken by universities are primarily "scientific." would have to satisfy all the conditions of this primary purpose, such as the dissemination requirement, in order to be exempt.

\section{B. Proposals Regarding the Tax on Unrelated Business Income}

As discussed above, some research activities disqualified as scientific research under $\S 501$ (c)(3) do not constitute "unrelated trade and business;" such activities are, therefore, not taxable. In addition to not being substantially related to an exempt function, to be taxable an activity must rise to the level of a trade or business, ${ }^{111}$ must be carried on regularly, ${ }^{112}$ and must not fall with one of the statutory exclusions. ${ }^{113}$

The limited scope of the unrelated business income tax results from Congress's specific intent ${ }^{114}$ - to eliminate a source of unfair competition by placing the unrelated business activities of certain exempt organizations on the same tax basis as the nonexempt business with which they compete. ${ }^{115}$ There is, however, a more convincing way of viewing the function of this tax that is consistent with the rationale for exempting research universities from tax. ${ }^{116}$ Although not taxing the income from unrelated activities will give the universities more money and freedom to initiate their own research, taxing the income from unrelated activities would en-

109. See supra notes $72-74$ and accompanying text.

110. Collaborative research does not include corporate gifts to universities that have no conditions attached.

111. See supra note 77 and accompanying text.

112. See supra note 78 and accompanying text.

113. See supra notes 84-93 and accompanying text.

114. See supra note 76 and accompanying text.

115. See id.

116. Several scholars have criticized the allegations that tax-exempt organizations compete unfairly. See, e.g., Rose-Ackerman, Unfair Competition and Corporate Income Taxation, 34 STAN. L. REv. 1017, 1026-36 (1982) (unfair competition may occur under oligopolistic market conditions or when nonprofit organizations enter a particular market unanticipated by profit-motivated competitors). 
courage the universities to comply with the minimal criteria of exemption proposed in this Note. More research does not necessarily mean more research of the type that the Code is trying to promote. Since the minimal criteria of exemption proposed in this Note allows for the continued development of basic research, all research activities not qualifying as scientific research within the meaning of the amended $\S 501$ (c)(3) should be taxable. The broad statutory exclusion to the definition of unrelated business income-of all income derived from research performed by colleges or universities-should be repealed, and the definition of unrelated trade or business should be modified accordingly.

\section{CoNCLUSION}

The exemption of nonprofit research colleges and universities from federal income taxation should not be viewed as a subsidy merely for good works. Rather, the exemption should be tied to the specific goal of encouraging basic research that benefits the public's welfare. As currently written and applied, the Code inadequately promotes this goal. It should therefore be amended to require that the results of tax-exempt research be both reported and used. 
